\title{
Effects of Growth Hormone Replacement Therapy on Bone Mineral Density in Growth Hormone Deficient Adults: A Meta-Analysis
}

\author{
Peng Xue, ${ }^{1}$ Yan Wang, Jie Yang, ${ }^{2}$ and Yukun $\mathrm{Li}^{1}$ \\ ${ }^{1}$ Department of Endocrinology, The Third Hospital of Hebei Medical University, 139 Ziqiang Road, \\ Shijiazhuang, Hebei 050000, China \\ ${ }^{2}$ Department of Epidemiology and Biostatistics, School of Public Health, Hebei Medical University, \\ 361 East Zhongshan Road, Shijiazhuang, Hebei 050000, China
}

Correspondence should be addressed to Yukun Li; liyukun@medmail.com.cn

Received 30 December 2012; Revised 8 March 2013; Accepted 13 March 2013

Academic Editor: Ling-Qing Yuan

Copyright (c) 2013 Peng Xue et al. This is an open access article distributed under the Creative Commons Attribution License, which permits unrestricted use, distribution, and reproduction in any medium, provided the original work is properly cited.

Objectives. Growth hormone deficiency patients exhibited reduced bone mineral density compared with healthy controls, but previous researches demonstrated uncertainty about the effect of growth hormone replacement therapy on bone in growth hormone deficient adults. The aim of this study was to determine whether the growth hormone replacement therapy could elevate bone mineral density in growth hormone deficient adults. Methods. In this meta-analysis, searches of Medline, Embase, and The Cochrane Library were undertaken to identify studies in humans of the association between growth hormone treatment and bone mineral density in growth hormone deficient adults. Random effects model was used for this meta-analysis. Results. A total of 20 studies (including one outlier study) with 936 subjects were included in our research. We detected significant overall association of growth hormone treatment with increased bone mineral density of spine, femoral neck, and total body, but some results of subgroup analyses were not consistent with the overall analyses. Conclusions. Our meta-analysis suggested that growth hormone replacement therapy could have beneficial influence on bone mineral density in growth hormone deficient adults, but, in some subject populations, the influence was not evident.

\section{Introduction}

The major role of growth hormone $(\mathrm{GH})$ during childhood is to promote bone growth and linear growth, but GH continues to have important metabolic actions throughout life. Besides growth, GH is known to affect body composition, bone mineralization, and lipid and glucose metabolism [1]. For instance, GH can accelerate bone turnover, which is supported by several lines of evidence. In vitro studies show that GH and its major effector, insulin-like growth factor-1 (IGF-1), are both mitogens for osteoblasts $[2,3]$.

The condition of GH deficiency (GHD) has been accepted as a definite syndrome, and the clinical and biochemical abnormalities in GHD patients are also well known. They involve mainly the cardiovascular system, lipid metabolism, body composition, mineral metabolism, and quality of life $[4,5]$. For example, adult patients with childhood-onset or adult-onset GHD exhibit reduced bone mineral density (BMD) compared with healthy controls [6, 7]. Moreover, clinical studies have shown that the prevalence of fractures is 2.7-3 times higher in GHD patients than in age-matched controls. Data from these studies suggest that the increased risk may be due to GHD rather than other pituitary hormone deficiencies $[8,9]$.

Many studies have demonstrated that the abnormalities of GHD patients may be reversed by GH replacement therapy, but the evidence is not all conclusive. In particular, the effect of GH treatment on BMD is less clear, though it is well established that $\mathrm{GH}$ promotes longitudinal bone growth. Some studies suggest an improvement in BMD [10], some show no effect [11], and others suggest a decrease in BMD related to GH treatment [12]. Moreover, the association 
between GH treatment and BMD may be influenced by other factors such as gender, treatment time, GH dosage, or geographic location.

We, therefore, undertook a meta-analysis on the effects of GH replacement therapy on BMD based on available studies.

\section{Methods}

2.1. Search Strategy and Inclusion Criteria. We systematically searched Medline, Embase, and Cochrane Library for studies written in English (from their commencements to December 2012). The search used the following terms: "growth hormone," "GH," "somatotropin," "bone," "bone mineral density" and "BMD." The following three sites of BMD were included in this meta-analysis: spine, femoral neck (FN), and total body (TB).

Studies in humans of the effects of GH treatment on $\mathrm{BMD}$, regardless of sample size, were included if they met the following criteria: (1) data were reported on at least one of the three sites (spine, FN, and TB) of BMD; (2) BMD was measured by dual-energy X-ray absorptiometry (DXA); (3) we only included studies in which mean BMD and standard deviations (SDs), or standard errors (SEs) were available; (4) adult subjects (>16 years old); (5) subjects were patients with GHD who received GH treatment. The excluded studies included reviews, editorials, comments, letters, and abstracts.

2.2. Data Extraction. Two investigators independently reviewed the articles and selected eligible studies according to the inclusion criteria for eligible studies. Irrelevant studies were excluded. For studies with the same population resources or overlapping datasets, the most complete one was included. Study details and data were extracted independently and to a standardized electronic form by two investigators, and discrepancies were adjudicated by a third reviewer until consensus was achieved on every item. The following information was extracted from each study: last name of first author, year of publication, country, subject population, mean, BMD and SDs (or SEs) of subjects at baseline and after GH treatment.

2.3. Statistical Analysis. For this meta-analysis, all data should be given as mean and SDs. In those studies, where values of SEs were originally reported, the values of SDs were calculated. When information was reported for more than one subpopulation in one study, each subpopulation was treated as a separate comparison in our meta-analysis. BMDs in the three sites (spine, FN, and TB) were continuous outcomes presented on different scales $\left(\mathrm{g} / \mathrm{cm}^{2}, z\right.$-scores or $t$ scores), so we used a pooled standardized mean difference (SMD) with $95 \%$ confidence intervals (CI) calculated using the final follow-up $P$ values to analyze the effects of $\mathrm{GH}$ treatment on BMD. All data were initially analyzed with a fixed effects model. If heterogeneity was found, the analysis should be redone using a random effects model. A $P$ value of 0.05 was considered statistically significant.

Heterogeneity of the effect across studies was assessed by $Q$ statistics, which is distributed as $\chi^{2}$ statistics. $I^{2}$ statistics were provided to quantify the percentage of total variation across studies that was attributable to heterogeneity rather than to chance. An $I^{2}$ value $>50 \%$ represented substantial variability, and heterogeneity was considered to be significant at $P<0.10$, a conservative standard for meta-analyses. In the presence of heterogeneity, sensitivity analyses were performed to identify the outlier studies. The influence of outliers was also assessed to evaluate the impact of their removal. Moreover, there might be effective modificationcaused by study-level characteristics including treatment time, $\mathrm{GH}$ dosage, manufacturer of DXA scanner, and geographic location. Thus, subgroup analyses were further conducted to detect the source of heterogeneity. Treatment time subgroups were defined as $\leq 2$ years or $>2$ years. GH dosage subgroups were defined as fixed dosage and dosage depending on serum IGF-1 values. Manufacturer of DXA scanner subgroups was defined as GE-Lunar or Hologic Inc, since the studies using other manufacturers of DXA scanner (Norland) are too few. Geographic location subgroups were defined as Europe, America, or Oceania.

We performed a visual inspection of the funnel plot for publication bias. The funnel plot should be asymmetric when there is publication bias and symmetric in the case of no publication bias. We performed Egger and Begg tests to measure the funnel plot asymmetry using a significance level of $P<0.05$.

All statistical analyses were performed by using STATA 11.0 (Stata Corporation, College Station, TX, USA). The results of our research were reported according to the Preferred Reporting Items for Systematic Reviews and MetaAnalyses (PRISMA) guidelines.

\section{Results}

3.1. Studies Included in the Meta-Analysis. Our literature search produced 657 citations written in English, of which we selected 69 for further review of the full text. A total of 49 studies were excluded for unavailable or incomplete data. Finally, 20 unique studies were available for this metaanalysis $[10,11,13-30]$. Of these, 18 studies (included 20 comparisons), 16 studies (included 18 comparisons), and 11 studies (included 12 comparisons) presented data on BMD of spine, FN, and TB, respectively. Tables 1 and 2 summarized the characteristics and the data of the included studies.

In all eligible studies, there were 3 studies separately providing the information on more than one subpopulation. Each subpopulation was treated as a separate comparison. A total of 936 subjects were included in this meta-analysis.

3.2. Association between GH Treatment and BMD of Spine. We initially performedthe meta-analysis on all 18 studies (including 20 comparisons) with a fixed effects model. For the presence of significant heterogeneity $\left(I^{2}=82.9 \%\right)$, the analysis wasredone using a random effects model. The results suggested significant association between GH treatment and increased BMD of spine (SMD $=0.540,95 \%$ CI [0.272, 0.808], $P<0.001 ; I^{2}=82.9 \%, P<0.001$ for $Q$ test $)$. 


\begin{tabular}{|c|c|c|c|}
\hline Study ID & & SMD (95\% CI) & Weight (\%) \\
\hline Hansen et al. (1996) & & $-0.06(-0.8,0.68)$ & 3.52 \\
\hline Johannsson et al. (1996) & $\rightarrow$ & $0.26(-0.16,0.68)$ & 6.73 \\
\hline Rodríguez-Arnao et al. (1998) & $\longrightarrow$ & $1.33(0.58,2.08)$ & 3.45 \\
\hline Biller et al. (2000) & & $0.34(-0.28,0.97)$ & 4.42 \\
\hline Lanzi et al. (2003) & & $0.17(-0.49,0.82)$ & 4.16 \\
\hline Underwood et al. 1 (2003) & & $0.22(-0.62,1.06)$ & 2.94 \\
\hline Underwood et al. 2 (2003) & & $0.29(-0.45,1.04)$ & 3.49 \\
\hline Hubina et al. 1 (2004) & & $0.35(-0.27,0.97)$ & 4.41 \\
\hline Hubina et al. 2 (2004) & & $0.53(-0.1,1.16)$ & 4.36 \\
\hline Bravenboer et al. (2005) & 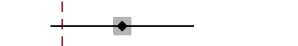 & $0.81(0.34,1.27)$ & 6.09 \\
\hline Arwert et al. (2005) & & $0.44(-0.14,1.03)$ & 4.78 \\
\hline Boguszewski et al. (2005) & & $0.05(-0.61,0.7)$ & 4.17 \\
\hline Benedini et al. (2006) & & $0.43(-0.38,1.24)$ & 3.09 \\
\hline Snyder et al. (2007) & $\rightarrow$ & $0.22(-0.26,0.71)$ & 5.89 \\
\hline Gotherstrom et al. (2007) & $\rightarrow$ & $0.34(0.04,0.64)$ & 8.55 \\
\hline Fideleff et al. (2008) & $\longrightarrow$ & $1.46(1.01,1.91)$ & 6.31 \\
\hline Conway et al. (2009) & $\rightarrow$ & $0.37(0.1,0.64)$ & 9.05 \\
\hline Van den Heijkant et al. (2011) & $\rightarrow \quad 1$ & $0.19(-0.32,0.7)$ & 5.62 \\
\hline Elbornsson et al. (2012) & $\rightarrow-1$ & $0.28(0.01,0.56)$ & 8.99 \\
\hline Overall $\left(I^{2}=50 \%, P=0.007\right)$ & & $0.43(0.26,0.59)$ & 100 \\
\hline Note: weights are from random effects analysis & & & \\
\hline $\begin{array}{c}1 \\
-2.08\end{array}$ & & .08 & \\
\hline
\end{tabular}

(a)

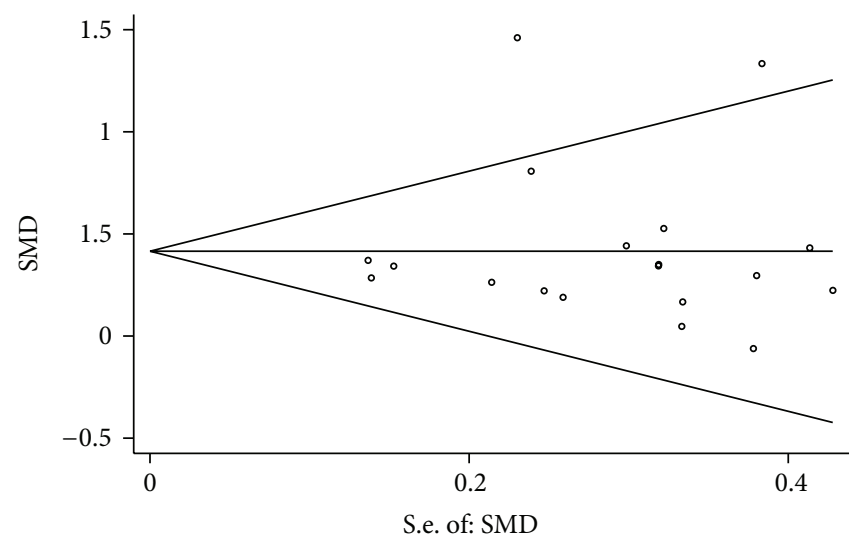

(b)

FIGURE 1: Forest plot and funnel plot for the association between GH treatment and BMD of spine. (a) Forest plot using a random effects model. (b) Funnel plot using Begg methods.

Sensitivity analyses showed that there was an outlier study (study ID: Rota et al.). When the outlier study was omitted, 17 studies (including 19 comparisons) were included in the meta-analysis. The heterogeneity was decreased and the results also suggested significant association between $\mathrm{GH}$ treatment and increased BMD of spine (SMD $=0.429,95 \%$ CI [0.263, 0.594], $P<0.001 ; I^{2}=50.0 \%, P=0.007$ for $Q$ test) (Figure 1(a)).

To further detect the source of heterogeneity, we performed subgroup analyses stratified by the characteristics (treatment time, GH dosage, manufacturer of DXA scanner, and geographic location) of the subjects. The results did not suggest significant association between $\mathrm{GH}$ treatment and
$\mathrm{BMD}$ of spine in American subjects $(\mathrm{SMD}=0.461,95 \% \mathrm{CI}$ $[-0.049,0.971], P=0.076 ; I^{2}=76.3 \%, P=0.001$ for $Q$ test). But a significant association between $\mathrm{GH}$ treatment and increased BMD of spine in the other subgroups was found. Significant heterogeneity was removed or decreased in some subgroups. Table 3 summarizes the subgroup analyses results.

3.3. Association between GH Treatment and BMD of FN. Similarly, we performed the meta-analysis on all 16 studies (including 18 comparisons) with arandom effects model. The results suggested significant association between $\mathrm{GH}$ treatment and increased $\mathrm{BMD}$ of $\mathrm{FN}(\mathrm{SMD}=0.476,95 \% \mathrm{CI}$ [0.190, 0.761], $P=0.001 ; I^{2}=83.0 \%, P<0.001$ for $Q$ test $)$. 


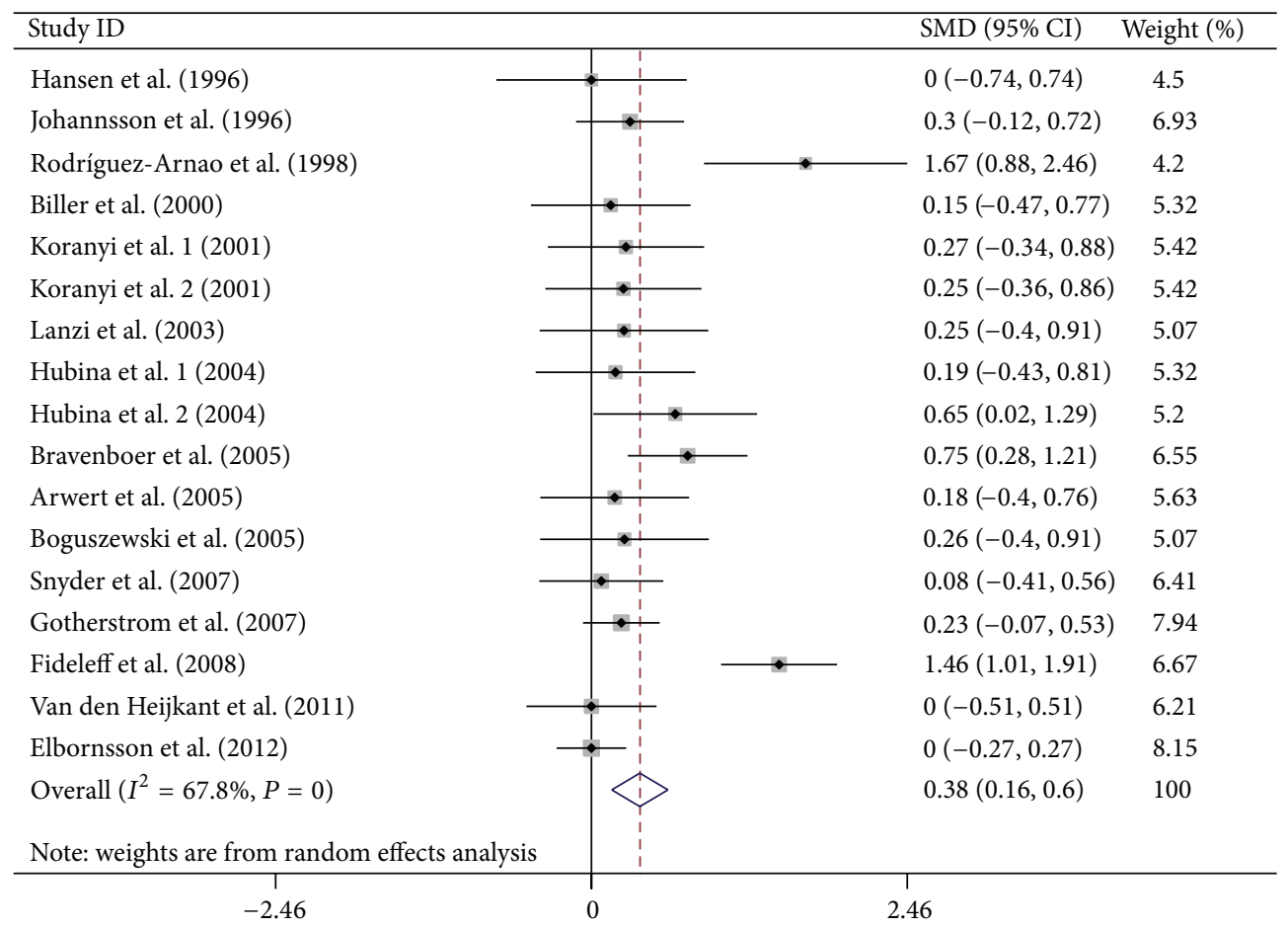

(a)

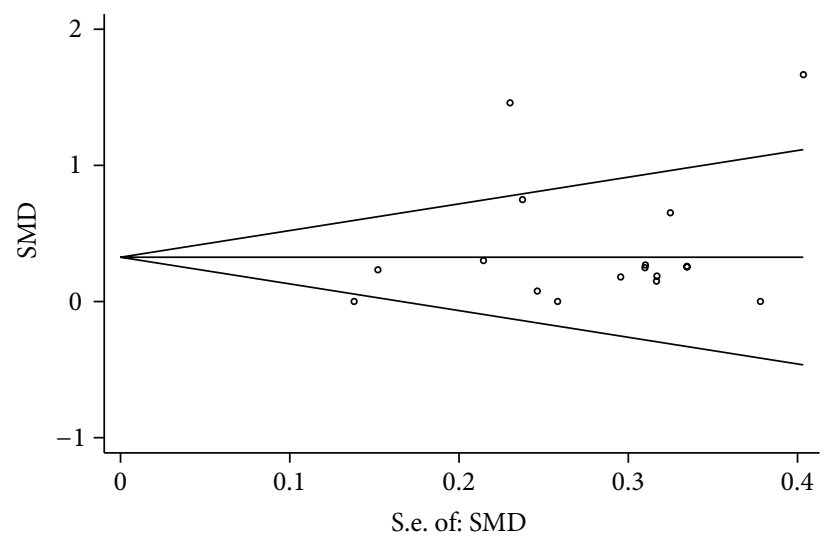

(b)

FIGURE 2: Forest plot and funnel plot for the association between GH treatment and BMD of FN. (a) Forest plot using a random effects model. (b) Funnel plot using Begg methods.

Sensitivity analyses showed that there was also an outlier study (study ID: Rota et al.). When the outlier study was omitted, 15 studies (including 17 comparisons) were included in the meta-analysis. The heterogeneity was decreased and the results also suggested significant association between GH treatment and increased BMD of FN (SMD $=0.377,95 \%$ CI [0.158, 0.595], $P=0.001 ; I^{2}=67.8 \%, P<0.001$ for $Q$ test $)$ (Figure 2(a)).

We also performed subgroup analyses to further detect the source of heterogeneity. The results did not suggest significant association between GH treatment and BMD of FN in subjects treated by GH for $\leq 2$ years (SMD $=0.289,95 \%$ CI [ $-0.009,0.587], P=0.057 ; I^{2}=51.2 \%, P=0.045$ for $Q$ test) and American subjects (SMD $=0.501,95 \%$ CI $[-0.227$,
1.229], $P=0.177 ; I^{2}=86.1 \%, P<0.001$ for $Q$ test). But significant association between GH treatment and increased $\mathrm{BMD}$ of FN in the other subgroups were found. Moreover, the significant heterogeneity was removed or decreased in some subgroups. Table 4 summarizes the subgroup analyses results.

3.4. Association between GH Treatment and BMD of TB. Analogously, we performed the meta-analysis on all 11 studies (including 12 comparisons) with a random effects model. The results suggested significant association between $\mathrm{GH}$ treatment and increased BMD of TB (SMD $=0.242,95 \%$ CI $[0.019,0.466], P=0.034 ; I^{2}=69.6 \%, P<0.001$ for $Q$ test $)$ (Figure 3(a)). 


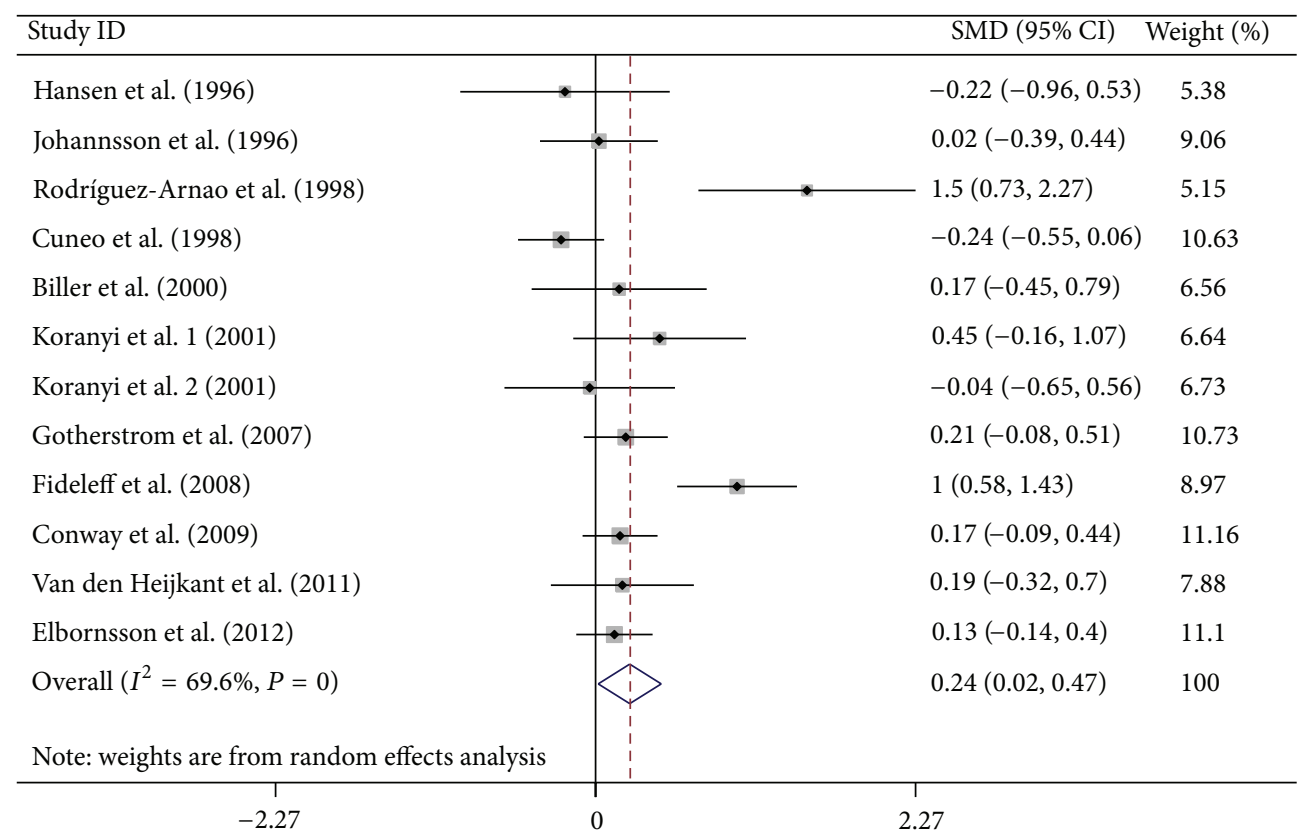

(a)

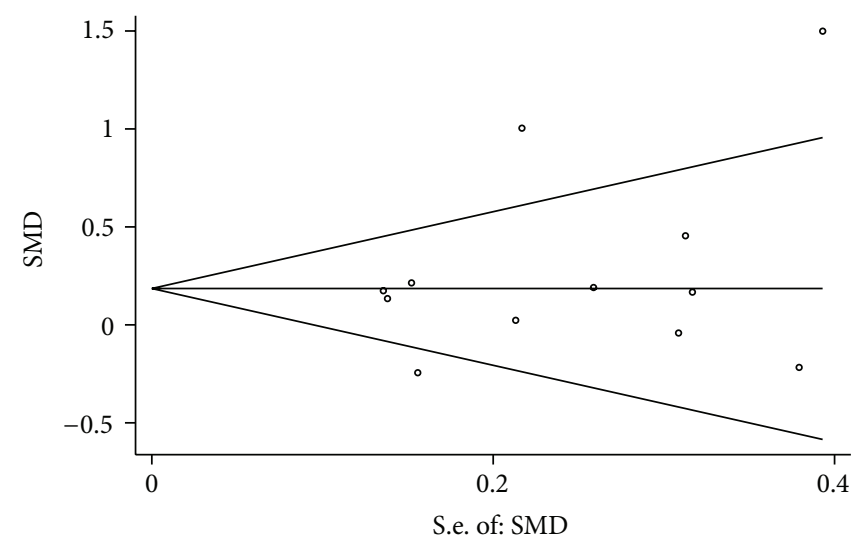

(b)

FIGURE 3: Forest plot and funnel plot for the association between GH treatment and BMD of TB. (a) Forest plot using a random effects model. (b) Funnel plot using Begg methods.

Sensitivity analyses showed that there was no outlier study.

We also performed subgroup analyses to further detect the source of heterogeneity. The results did not suggest significant association between GH treatment and BMD of $\mathrm{TB}$ in subjects with treatment time $\leq 2$ years $(\mathrm{SMD}=0.159$, 95\% CI [-0.148, 0.466], $P=0.311 ; I^{2}=68.1 \%, P=0.004$ for $Q$ test), subjects who received fixed $\mathrm{GH}$ dosage $(\mathrm{SMD}=0.205$, $95 \%$ CI $[-0.406,0.816], P=0.512 ; I^{2}=82.7 \%, P=0.001$ for $Q$ test), subjects whose BMD was measured by DXA scanner manufactured by Hologic Inc (SMD $=0.317,95 \%$ CI $[-0.101$, 0.736], $P=0.137 ; I^{2}=66.8 \%, P=0.017$ for $Q$ test), subjects whose BMD was measured by DXA scanner manufactured by GE-Lunar Inc (SMD $=0.207,95 \%$ CI $[-0.083,0.497], P=$ $0.162 ; I^{2}=74.8 \%, P=0.001$ for $Q$ test), European subjects $\left(\mathrm{SMD}=0.224,95 \% \mathrm{CI}[-0.015,0.463], P=0.066 ; I^{2}=51.2 \%\right.$,
$P=0.045$ for $Q$ test), American subjects (SMD $=0.618,95 \%$ CI $[-0.200,1.435], P=0.139 ; I^{2}=78.9 \%, P<0.029$ for $Q$ test,) and Oceanian subjects (SMD $=-0.028,95 \% \mathrm{CI}[-0.438$, 0.381], $P=0.892 ; I^{2}=75.6 \%, P=0.043$ for $Q$ test), but as significant association between $\mathrm{GH}$ treatment and increased $\mathrm{BMD}$ of TB in the other subgroups was found. Moreover, the significant heterogeneity was removed or decreased in some subgroups. Table 5 summarizes the subgroup analyses results.

3.5. Heterogeneity and Publication Bias. Significant heterogeneity was separately observed among the available studies on BMD of spine, FN, and TB. To detect the source of heterogeneity, we performed subgroup analyses stratified by the characteristics of the subjects. Significant heterogeneity was removed or decreased in some subgroups but still existed in other subgroups. 
TABLE 1: Patient characteristics in included studies.

\begin{tabular}{|c|c|c|c|c|c|}
\hline References & Countries & Study subjects & Criteria of GHD & $\begin{array}{c}\text { Treatment } \\
\text { time }\end{array}$ & GH usage \\
\hline $\begin{array}{l}\text { Hansen et al., } \\
1996[13]\end{array}$ & Denmark & $\begin{array}{l}9 \text { males and } 5 \text { females aged } \\
31-57\end{array}$ & $\begin{array}{l}<10 \mathrm{mU} / \mathrm{L} \text { in } \\
\mathrm{ITT}^{\mathrm{a}}\end{array}$ & $1 \mathrm{yr}$ & $2.0 \mathrm{IU} / \mathrm{m}^{2} \cdot$ day \\
\hline $\begin{array}{l}\text { Johannsson } \\
\text { et al., } 1996 \text { [14] }\end{array}$ & Sweden & $\begin{array}{l}24 \text { males and } 20 \text { females aged } \\
23-66\end{array}$ & $<5 \mathrm{mU} / \mathrm{L}$ in ITT & $2 \mathrm{yr}$ & $\begin{array}{l}\text { First } 4 \text { weeks: } 0.1 \mathrm{IU} / \mathrm{kg} \cdot \text { week } \\
\text { Thereafter: } 0.25 \mathrm{IU} / \mathrm{kg} \cdot \text { week }\end{array}$ \\
\hline $\begin{array}{l}\text { Rodríguez- } \\
\text { Arnao et al., } \\
1998[15]\end{array}$ & UK & $\begin{array}{l}18 \text { males and } 17 \text { females aged } \\
\text { 21.1-59.9 }\end{array}$ & $\begin{array}{l}<10 \mathrm{mU} / \mathrm{L} \text { in } \\
\text { ITT }\end{array}$ & $1 \mathrm{yr}$ & $\begin{array}{l}\text { First } 4 \text { weeks: } 0.125 \mathrm{IU} / \mathrm{kg} \cdot \text { week } \\
\text { Thereafter: } 0.25 \mathrm{IU} / \mathrm{kg} \cdot \text { week }\end{array}$ \\
\hline $\begin{array}{l}\text { Cuneo et al., } \\
1998[16]\end{array}$ & Australia & $\begin{array}{l}50 \text { males and } 33 \text { females aged } \\
41.2 \pm 1.5\end{array}$ & $<5 \mathrm{mU} / \mathrm{L}$ in ITT & $1 \mathrm{yr}$ & $\begin{array}{l}\text { First month: } 0.125 \mathrm{IU} / \mathrm{kg} \cdot \text { week } \\
\text { Thereafter: } 0.25 \mathrm{IU} / \mathrm{kg} \cdot \text { week }\end{array}$ \\
\hline $\begin{array}{l}\text { Biller et al., } 2000 \\
{[17]}\end{array}$ & USA & 38 males aged $48.9 \pm 2.0$ & $\mathrm{NA}^{\mathrm{b}}$ & $1.5 \mathrm{yr}$ & $\begin{array}{l}\text { Initial dose: } 10 \mu \mathrm{g} / \mathrm{kg} \cdot \text { day } \\
\text { Then adjusted accordingly to the serum } \\
\text { IGF-I values }\end{array}$ \\
\hline $\begin{array}{l}\text { Koranyi et al., } \\
2001[18]\end{array}$ & Sweden & $\begin{array}{l}28 \text { males and } 14 \text { females aged } \\
\qquad 17-61\end{array}$ & NA & $5 \mathrm{yr}$ & $\begin{array}{l}\text { Initial dose: } 0.25 \mathrm{IU} / \mathrm{kg} \cdot \text { week } \\
\text { Then adjusted accordingly to the serum } \\
\text { IGF-I values }\end{array}$ \\
\hline $\begin{array}{l}\text { Lanzi et al., } 2003 \\
{[19]}\end{array}$ & Italy & $\begin{array}{l}10 \text { males and } 8 \text { females aged } \\
\qquad 17-50\end{array}$ & $\begin{array}{c}<9 \mu \mathrm{g} / \mathrm{L} \text { in } \\
\mathrm{ARG}^{\mathrm{c}}\end{array}$ & $0.5 \mathrm{yr}$ & $\begin{array}{l}\text { Initial dose: } 4 \mu \mathrm{g} / \mathrm{kg} \cdot \text { day } \\
\text { Then adjusted accordingly to the serum } \\
\text { IGF-I values }\end{array}$ \\
\hline $\begin{array}{l}\text { Underwood } \\
\text { et al., } 2003[20]\end{array}$ & USA & $\begin{array}{l}39 \text { males and } 25 \text { females aged } \\
\qquad 23.8 \pm 4.2\end{array}$ & $\begin{array}{c}<5 \mu \mathrm{g} / \mathrm{L} \text { in } \\
\text { clonidine and } \\
\text { L-dopa } \\
\text { stimulation tests }\end{array}$ & $2 \mathrm{yr}$ & $\begin{array}{l}25 \mu \mathrm{g} / \mathrm{kg} \cdot \text { day or } \\
12.5 \mu \mathrm{g} / \mathrm{kg} \cdot \text { day }\end{array}$ \\
\hline $\begin{array}{l}\text { Hubina et al., } \\
2004[21]\end{array}$ & Hungary & $\begin{array}{l}11 \text { males and } 9 \text { females aged } \\
22-67\end{array}$ & $\begin{array}{c}<3 \mu \mathrm{g} / \mathrm{L} \text { in ITT } \\
\text { or ARG }\end{array}$ & $3 y r$ & $1.2 \mathrm{IU} /$ day (average dose) \\
\hline $\begin{array}{l}\text { Bravenboer } \\
\text { et al., } 2005 \text { [22] }\end{array}$ & The Netherlands & 38 males aged $20-35$ & $\begin{array}{l}<7 \mu \mathrm{g} / \mathrm{L} \text { in ITT } \\
\text { or } \mathrm{GHRH}^{\mathrm{d}}\end{array}$ & $5 \mathrm{yr}$ & $0.67 \mathrm{mg} / \mathrm{m}^{2} \cdot$ day \\
\hline $\begin{array}{l}\text { Arwert et al., } \\
2005[23]\end{array}$ & The Netherlands & 23 males aged $20-40$ & $\begin{array}{l}<7 \mu \mathrm{g} / \mathrm{L} \text { in ITT } \\
\quad \text { or } \mathrm{GHRH}\end{array}$ & $10 \mathrm{yr}$ & $\begin{array}{l}\text { First } 0.5 \mathrm{yr}: 1.2 \text { or } 3 \mathrm{IU} / \mathrm{m}^{2} \cdot \text { day } \\
0.5-2 \mathrm{yr}: 2 \mathrm{IU} / \mathrm{m}^{2} \cdot \text { day } \\
\text { Then adjusted accordingly to the serum } \\
\text { IGF-I values }\end{array}$ \\
\hline $\begin{array}{l}\text { Boguszewski } \\
\text { et al., } 2005 \text { [24] }\end{array}$ & Brazil & $\begin{array}{l}7 \text { males and } 11 \text { females aged } \\
21-58 \\
\end{array}$ & $<3 \mu \mathrm{g} / \mathrm{L}$ in ITT & $1 \mathrm{yr}$ & $0.6 \mathrm{IU} /$ day \\
\hline $\begin{array}{l}\text { Benedini et al., } \\
2006[25]\end{array}$ & Italy & $\begin{array}{l}6 \text { males and } 6 \text { females aged } \\
\qquad 29-54\end{array}$ & $\begin{array}{l}<9 \mu \mathrm{g} / \mathrm{L} \text { in } \mathrm{ARG} \\
\text { and GHRH }\end{array}$ & $1 \mathrm{yr}$ & $\begin{array}{l}\text { Initial dose: } 0.25 \mathrm{mg} / \mathrm{day} \text { (for men) or } \\
0.4 \mathrm{mg} / \text { day (for women) } \\
\text { Then adjusted accordingly to the serum } \\
\text { IGF-I values }\end{array}$ \\
\hline $\begin{array}{l}\text { Snyder et al., } \\
2007[26]\end{array}$ & USA & $\begin{array}{l}20 \text { males and } 13 \text { females aged } \\
\qquad 29-54\end{array}$ & $\begin{array}{l}<2.4 \mu \mathrm{g} / \mathrm{L} \text { in } \\
\text { ITT or ARG }\end{array}$ & $2 \mathrm{yr}$ & $\begin{array}{l}\text { Initial dose: } 2 \mu \mathrm{g} / \mathrm{kg} \cdot \text { day } \\
\text { Then adjusted accordingly to the serum } \\
\text { IGF-I values }\end{array}$ \\
\hline $\begin{array}{l}\text { Gotherstrom } \\
\text { et al., } 2007 \text { [27] }\end{array}$ & Sweden & $\begin{array}{l}52 \text { males and } 35 \text { females aged } \\
\qquad 22-74\end{array}$ & $<3 \mu \mathrm{g} / \mathrm{L}$ in ITT & $10 \mathrm{yr}$ & $\begin{array}{l}64 \text { patients: the initial dose was } \\
0.25 \mathrm{IU} / \mathrm{kg} \cdot \text { week and then individualized } \\
23 \text { patients: the dose was individualized } \\
\text { from the start of the treatment }\end{array}$ \\
\hline $\begin{array}{l}\text { Rota et al., } 2008 \\
{[28]}\end{array}$ & Italy & $\begin{array}{l}35 \text { males and } 29 \text { females aged } \\
\qquad 30-50\end{array}$ & $\begin{array}{l}<9 \mu \mathrm{g} / \mathrm{L} \text { in } \mathrm{ARG} \\
\text { and } \mathrm{GHRH}\end{array}$ & $2 \mathrm{yr}$ & $\begin{array}{l}\text { Initial dose: } 4 \mu \mathrm{g} / \mathrm{kg} \cdot \text { day } \\
\text { Then adjusted accordingly to the serum } \\
\text { IGF-I values }\end{array}$ \\
\hline $\begin{array}{l}\text { Fideleff et al., } \\
2008[10]\end{array}$ & Argentina & $\begin{array}{l}22 \text { males and } 26 \text { females aged } \\
\qquad 18-66\end{array}$ & $\begin{array}{l}<0.14 \mathrm{pmol} / \mathrm{L} \text { in } \\
\text { ITT }\end{array}$ & $4 \mathrm{yr}$ & $\begin{array}{l}\text { Initial dose: } 0.1 \mathrm{mg} / \text { day } \\
\text { Then adjusted accordingly to the serum } \\
\text { IGF-I values }\end{array}$ \\
\hline $\begin{array}{l}\text { Conway et al., } \\
2009 \text { [29] }\end{array}$ & Australia & $\begin{array}{l}65 \text { males and } 44 \text { females aged } \\
\qquad 21.1 \pm 2.3\end{array}$ & $<3 \mu \mathrm{g} / \mathrm{L}$ in ITT & $2 \mathrm{yr}$ & $\begin{array}{l}\text { Initial dose: } 0.2 \mathrm{mg} / \mathrm{day} \text { (for men) or } \\
0.4 \mathrm{mg} / \text { day (for women) } \\
\text { Then adjusted accordingly to the serum } \\
\text { IGF-I values }\end{array}$ \\
\hline
\end{tabular}


TABle 1: Continued.

\begin{tabular}{|c|c|c|c|c|c|}
\hline References & Countries & Study subjects & Criteria of GHD & $\begin{array}{l}\text { Treatment } \\
\text { time }\end{array}$ & GH usage \\
\hline $\begin{array}{l}\text { van den } \\
\text { Heijkant et al., } \\
2011[11] \\
\end{array}$ & The Netherlands & $\begin{array}{l}12 \text { males and } 8 \text { females aged } \\
23.9 \pm 3.0\end{array}$ & $<3 \mu \mathrm{g} / \mathrm{L}$ in ITT & $2 \mathrm{yr}$ & $\begin{array}{l}\text { Initial dose: } 0.1 \mathrm{mg} / \mathrm{m}^{2} \cdot \text { day } \\
\text { Then adjusted accordingly to the serum } \\
\text { IGF-I values }\end{array}$ \\
\hline $\begin{array}{l}\text { Elbornsson } \\
\text { et al., } 2012 \text { [30] }\end{array}$ & Sweden & $\begin{array}{l}72 \text { males and } 54 \text { females aged } \\
\qquad 22-74\end{array}$ & $\begin{array}{l}<3 \mu \mathrm{g} / \mathrm{L} \text { in ITT } \\
\text { or GHRH }\end{array}$ & $15 \mathrm{yr}$ & $\begin{array}{l}64 \text { patients: the initial dose was } \\
0.25 \mathrm{IU} / \mathrm{kg} \cdot \text { week and then individualized } \\
62 \text { patients: the dose was individualized } \\
\text { from the start of the treatment }\end{array}$ \\
\hline
\end{tabular}

${ }^{\mathrm{a}}$ Insulin tolerance test; ${ }^{\mathrm{b}}$ not available; ${ }^{\mathrm{c}}$ arginine test; ${ }^{\mathrm{d}} \mathrm{GH}$-releasing hormone.

For the 17 studies (with an outlier study excluded) focusing on BMD of spine, both Egger's regression $(P=0.789)$ and Begg methods $(P=0.889)$ did not show publication bias (Figure 1(b)). For the 15 studies (with an outlier study excluded) focusing on BMD of FN, both Egger's regression $(P=0.285)$ and Begg methods $(P=0.303)$ did not show publication bias (Figure 2(b)). For the 11 studies focusing on BMD of TB, both Egger's regression $(P=0.309)$ and Begg methods $(P=0.631)$ did not show publication bias (Figure 3(b)).

\section{Discussion}

In our meta-analysis, we detected an outlier study (study ID: Rota 2008) through sensitivity analyses when we performed the meta-analysis on the association of GH treatment and $\mathrm{BMD}$ of spine and FN. In the study mentioned above, patients aged below 30 years and above 50 years were excluded, which might make it an outlier study.

We detected significant overall association between $\mathrm{GH}$ treatment and increased BMD of spine, FN, and TB. GH could exert both direct and indirect effects on bone. (1) For direct effects on bone, there was increasing evidence that the GH-IGF axis played a vital role in determining BMD and maintaining bone health and that perturbations in this axis might predispose to the development of osteoporosis. Although GH could act on cells directly through specific receptors [31,32], most of its anabolic actions were mediated through IGF-1 [33-35]. GH stimulated the secretion of IGF1, largely from the liver, which then acted in an endocrine fashion. GH also stimulated IGF-1 locally in target tissues such as bone, where it might act in a paracrine or autocrine fashion $[36,37]$. Thus, the effect of GH on bone was mediated, at least in part by IGF-1, and bone mass was known to be linked to circulating levels of IGF-1 [38]. In vitro studies had shown that GH-IGF-1 bound to preosteoblasts or mature osteoblasts to induce differentiation and proliferation while also regulating osteoclastic differentiation and activity providing a mechanism to couple bone resorption and formation $[39,40]$. In addition, $\mathrm{GH}$ also increased biomarkers of bone turnover in normal subjects as well as adults and children with GHD [13, 41]. In almost all of the included studies in our meta-analysis, the serum IGF1 levels of adult GHD patients were significantly increased by the GH treatment, which were listed in Table 2. (2) For indirect effects on bone,
It was known that GH had an anabolic effect on skeletal muscle, and it particularly seemed to increase muscle mass and isometric muscle strength when given in physiologically therapeutic doses to GHD patients. Klefter and FeldtRasmussen analyzed many trials measuring effects of $\mathrm{GH}$ on both muscle and bones [42], and then suggested that there could be a connection between increases in muscle mass and strength and changes in BMD in GHD patients treated with GH. This supported the present physiological concept that the mass and strength of bones were primarily determined by dynamic loads from the skeletal muscles $[43,44]$.

Significant heterogeneity was found in our meta-analysis. Several study-level variables leading to heterogeneity were defined by subgroup analyses including treatment time, GH dosage, manufacturer of DXA scanner and geographic location. Some results of subgroup analyses were not consistent with the overall analyses.

Firstly, we did not detect significant association between GH treatment and BMD of FN and TB in subjects with treatment time $\leq 2 \mathrm{yr}$. GH-IGF1 stimulated bone remodeling which occurred as a biphasic process, dominated initially by bone resorption and only later by bone formation. This biphasic sequence might also explain the initial decrease in BMD reported in several clinical trials $[45,46]$. Thus, significant increases in BMD did not usually occur until 1224 months of treatment, and clinical trials with duration of 24 months or less might not be expected to find significant increases in bone parameters.

Secondly, we did not detect significant association between $\mathrm{GH}$ treatment and $\mathrm{BMD}$ of $\mathrm{TB}$ in subjects received fixed GH dosage (weight- or surface-area-based dosing regimens). Early studies used weight- or surface-area-based dosing regimens that resulted in a higher GH dose than titrating GH dose to normalize the serum IGF-1 level in subsequent years [47]. And the use of dose titration means that it takes longer to establish the patient on a maintenance $\mathrm{GH}$ dose. Thus, known differences in the time until response of $\mathrm{BMD}$ to $\mathrm{GH}$ are recognized. In our meta-analysis, $\mathrm{GH}$ treatment time in the studies which determined the $\mathrm{GH}$ dosage depending on serum IGF-1 level is mostly longer than that isthe studies which used fixed GH dosage. So, the effect of the former dosing regimens on BMD might be more evident.

Thirdly, we did not detect significant association between $\mathrm{GH}$ treatment and $\mathrm{BMD}$ of $\mathrm{TB}$ in the subjects whose $\mathrm{BMD}$ 


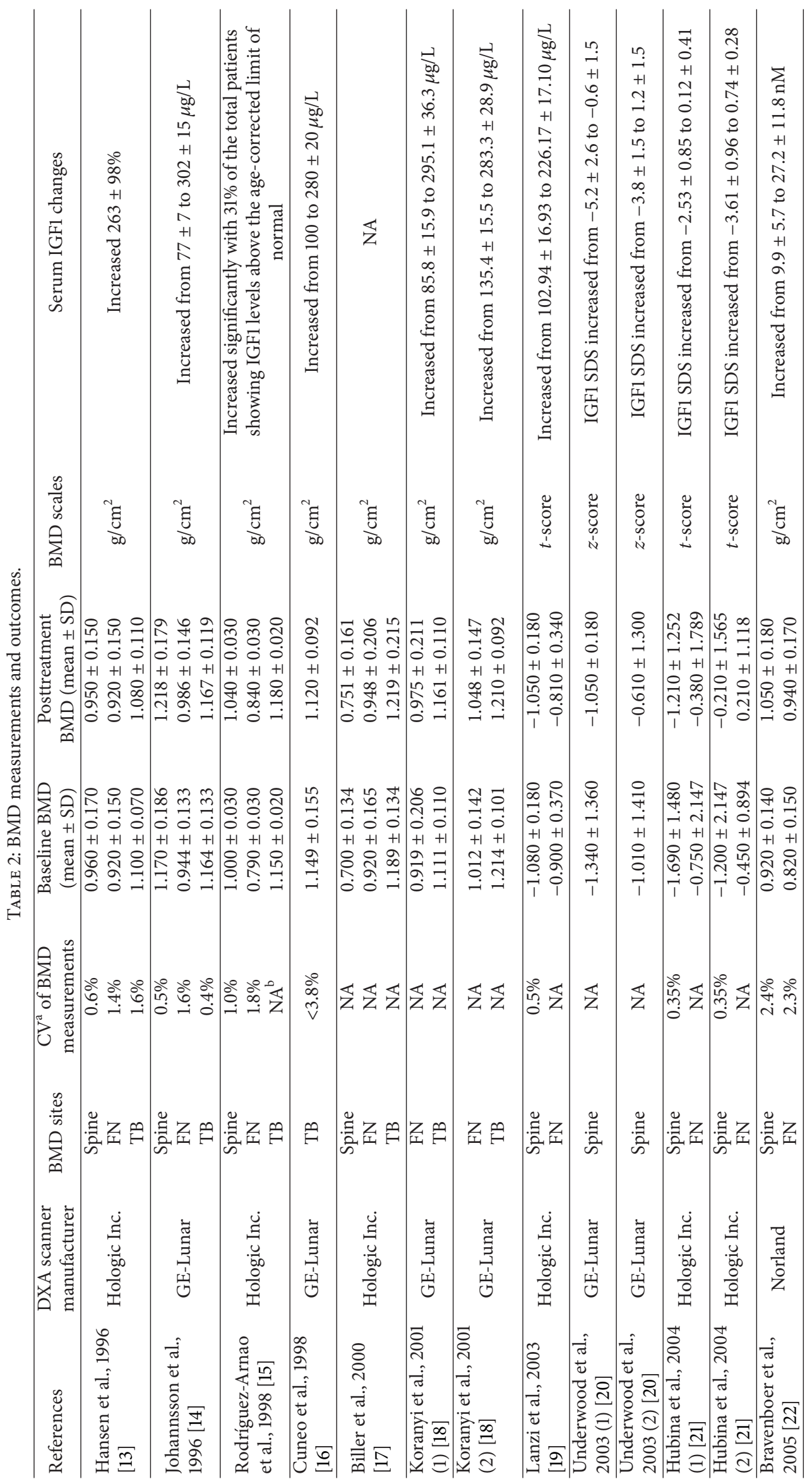




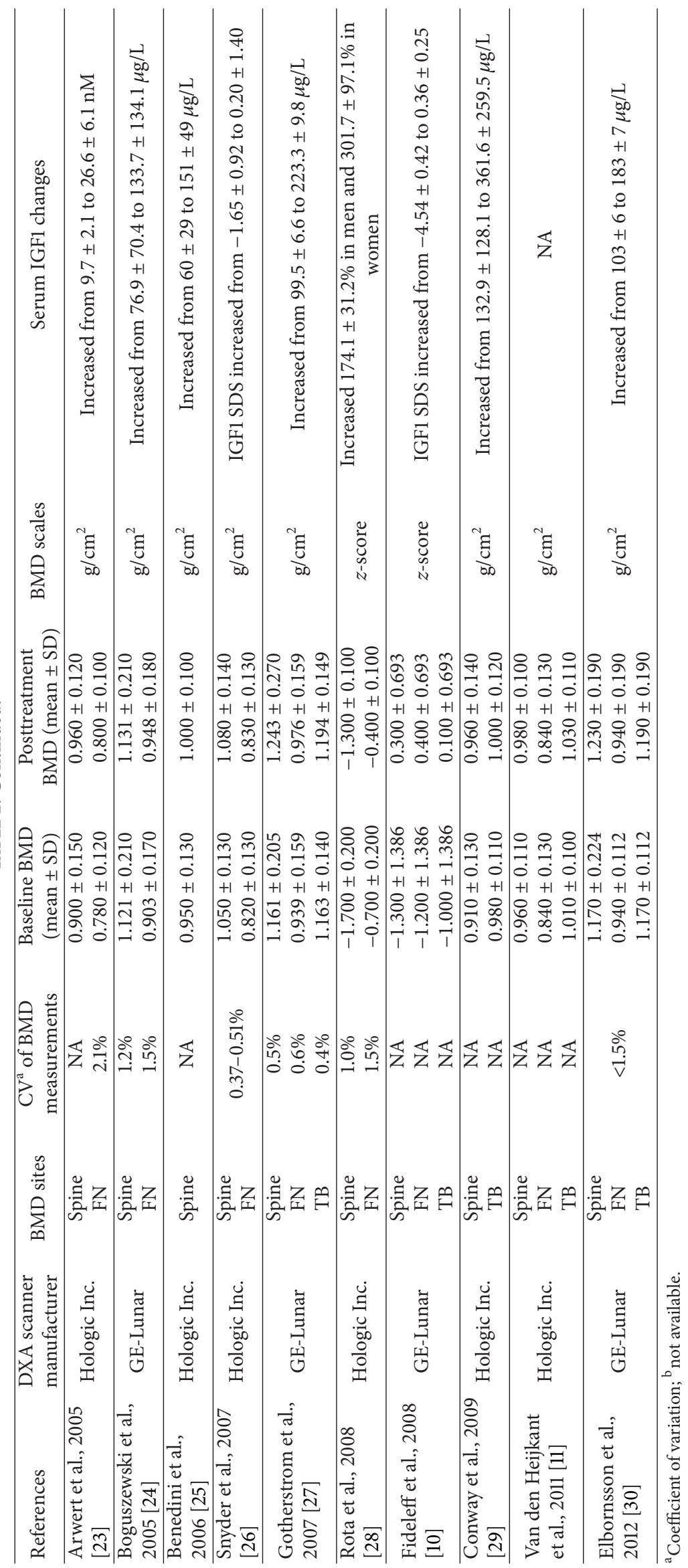


TABLE 3: Subgroup analyses results of the association between GH treatment and BMD of spine

\begin{tabular}{|c|c|c|c|c|c|c|}
\hline \multirow{2}{*}{ Subgroups } & \multicolumn{3}{|c|}{ Effects of GH treatment on BMD } & \multicolumn{3}{|c|}{ Heterogeneity } \\
\hline & SMD & $95 \% \mathrm{CI}$ & $P$ & $I^{2}(\%)$ & $\chi^{2}$ & $P$ \\
\hline \multicolumn{7}{|l|}{ Treatment time } \\
\hline$\leq 2 \mathrm{yr}$ & 0.311 & $0.159-0.463$ & 0.000 & 0.0 & 9.62 & 0.565 \\
\hline$>2 \mathrm{yr}$ & 0.597 & $0.275-0.919$ & 0.000 & 73.6 & 22.69 & 0.001 \\
\hline \multicolumn{7}{|l|}{ GH dosage } \\
\hline Fixed dosage & 0.429 & $0.172-0.686$ & 0.001 & 34.2 & 12.16 & 0.144 \\
\hline Dosage depending on serum IGF-1 values & 0.429 & $0.203-0.655$ & 0.000 & 62.2 & 23.79 & 0.005 \\
\hline \multicolumn{7}{|l|}{ Manufacturer of DXA scanner } \\
\hline Hologic Inc & 0.362 & $0.204-0.520$ & 0.000 & 0.0 & 9.15 & 0.518 \\
\hline GE-lunar & 0.440 & $0.097-0.783$ & 0.012 & 74.7 & 23.72 & 0.001 \\
\hline \multicolumn{7}{|l|}{ Geographic location $^{\mathrm{a}}$} \\
\hline Europe & 0.385 & $0.232-0.537$ & 0.000 & 13.9 & 12.78 & 0.308 \\
\hline America & 0.461 & $-0.049-0.971$ & 0.076 & 76.3 & 21.07 & 0.001 \\
\hline
\end{tabular}

${ }^{a}$ There was only one study including Oceanian subjects.

TABLE 4: Subgroup analyses results of the association between GH treatment and BMD of FN.

\begin{tabular}{|c|c|c|c|c|c|c|}
\hline \multirow{2}{*}{ Subgroups } & \multicolumn{3}{|c|}{ Effects of GH treatment on BMD } & \multicolumn{3}{|c|}{ Heterogeneity } \\
\hline & SMD & $95 \% \mathrm{CI}$ & $P$ & $I^{2}(\%)$ & $\chi^{2}$ & $P$ \\
\hline \multicolumn{7}{|l|}{ Treatment time } \\
\hline$\leq 2 \mathrm{yr}$ & 0.289 & $-0.009-0.587$ & 0.057 & 51.2 & 14.36 & 0.045 \\
\hline$>2 \mathrm{yr}$ & 0.440 & $0.119-0.761$ & 0.007 & 76.9 & 34.70 & 0.000 \\
\hline \multicolumn{7}{|l|}{ GH usage } \\
\hline Fixed dosage & 0.520 & $0.178-0.861$ & 0.003 & 56.5 & 13.79 & 0.032 \\
\hline Dosage depending on serum IGF-1 values & 0.289 & $0.007-0.571$ & 0.045 & 72.3 & 32.51 & 0.000 \\
\hline \multicolumn{7}{|l|}{ Manufacturer of DXA scanner } \\
\hline Hologic Inc & 0.306 & $0.018-0.595$ & 0.037 & 49.7 & 15.89 & 0.044 \\
\hline GE-lunar & 0.392 & $0.026-0.758$ & 0.036 & 80.2 & 30.34 & 0.000 \\
\hline \multicolumn{7}{|l|}{ Geographic location $^{a}$} \\
\hline Europe & 0.313 & $0.117-0.508$ & 0.002 & 48.0 & 23.08 & 0.027 \\
\hline America & 0.501 & $-0.227-1.229$ & 0.177 & 86.1 & 21.54 & 0.000 \\
\hline
\end{tabular}

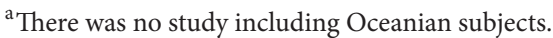

TABLE 5: Subgroup analyses results of the association between GH treatment and BMD of TB.

\begin{tabular}{|c|c|c|c|c|c|c|}
\hline \multirow{2}{*}{ Subgroups } & \multicolumn{3}{|c|}{ Effects of GH treatment on BMD } & \multicolumn{3}{|c|}{ Heterogeneity } \\
\hline & SMD & $95 \% \mathrm{CI}$ & $P$ & $I^{2}(\%)$ & $\chi^{2}$ & $P$ \\
\hline \multicolumn{7}{|l|}{ Treatment time } \\
\hline$\leq 2 \mathrm{yr}$ & 0.159 & $-0.148-0.466$ & 0.311 & 68.1 & 18.81 & 0.004 \\
\hline$>2 \mathrm{yr}$ & 0.352 & $0.015-0.688$ & 0.041 & 70.9 & 13.76 & 0.008 \\
\hline \multicolumn{7}{|l|}{ GH usage } \\
\hline Fixed dosage & 0.205 & $-0.406-0.816$ & 0.512 & 82.7 & 17.35 & 0.001 \\
\hline Dosage depending on serum IGF-1 values & 0.283 & $0.076-0.491$ & 0.007 & 52.0 & 14.59 & 0.042 \\
\hline \multicolumn{7}{|l|}{ Manufacturer of DXA scanner } \\
\hline Hologic Inc & 0.317 & $-0.101-0.736$ & 0.137 & 66.8 & 12.06 & 0.017 \\
\hline GE-lunar & 0.207 & $-0.083-0.497$ & 0.162 & 74.8 & 23.77 & 0.001 \\
\hline \multicolumn{7}{|l|}{ Geographic location } \\
\hline Europe & 0.224 & $-0.015-0.463$ & 0.066 & 51.2 & 14.34 & 0.045 \\
\hline America & 0.618 & $-0.200-1.435$ & 0.139 & 78.9 & 4.75 & 0.029 \\
\hline Oceania & -0.028 & $-0.438-0.381$ & 0.892 & 75.6 & 4.10 & 0.043 \\
\hline
\end{tabular}


was measured by DXA scanner manufactured by Hologic Inc or GE-lunar but got a significant overall association between GH treatment and increased BMD of TB. Absolute values of BMD, using DXA, might differ between instruments from different manufacturers. previous study performed a comparison of longitudinal measurements in the spine and proximal femur using lunar and Hologic instruments [48]. Despite the significant correlations, the agreement between the two densitometers was not high and there might be significant errors in individual subjects if one uses measurements from one densitometer to predict the change in BMD using the scanner of the other manufacturer. Furthermore, there were three studies (study ID: Arwert 2005, Gotherstrom 2007, Elbornsson 2012) which lasted for more than 10 years included in our meta-analysis. In the three studies, the operating criterion of BMD measurements changed partly during the GH treatment. In the study reported by Arwert et al., BMD measurements were performed with Norland XR26 at the beginning of the study, and with Hologic QDR-4500 at the end of the study, but they tried to resolve this problem. They measured the European Spine Phantom (ESP) on both devices, and the results of ESP measurements showed very similar BMD values. In the study reported by Gotherstrom et al., the software versions of Lunar DPX-L were changed several times (from 1.1 to finally 1.35) during the study, but the version 1.33 was generally used during the large period of the study. In the study reported by Elbornsson et al., BMD measurements were performed with LUNAR DPX-L scanner at the beginning of the study and with LUNAR Prodigy scanner at the end of the study. They measured 31 subjects' BMD with both scanners on the same day, and the BMD values of the subjects were not significantly different between scanners.

Fourthly, we did not detect significant association between GH treatment and BMD of spine, F, and TB in American subjects. In addition, we did not detect significant association between GH treatment and BMD of TB in European and Oceanian subjects but got a significant overall association between $\mathrm{GH}$ treatment and increased BMD of TB. Although GH was a major regulator of IGF-1 concentrations, other factors such as nutrition and insulin concentration were also important in its regulation. In different countries or geographic location, the nutrition or insulin concentration of GHD patients might also be different.

Heterogeneity was removed or decreased in some subgroups but still existed in other subgroups. Thus, in addition to treatment time, GH dosage, manufacturer of DXA scanner and geographic location, there might be other factors leading to heterogeneity. For instance, previous study indicated that gender might influence the association between GH treatment and BMD, and several studies suggested that men had a greater treatment response to GH replacement than women. The mechanisms underlying these gender differences were not fully understood, but sex hormones might play a role $[49,50]$. However, there were too few studies analyzing the results of GH treatment separately for males and females in the studies included in our meta-analysis, which made it impossible to undertake subgroup analyses stratified by gender. For the studies focus on BMD of spine, FN and
TB, both Egger's regression and Begg methods did not show publication bias.

In our study, we mainly investigated the effects of $\mathrm{GH}$ treatment on BMD in adult GHD patients. Besides its beneficial effects on bone, GH treatment is also suggested to alleviate at least some of the aspects of the reduced physical and psycHological health associated with GHD in adult life $[51,52]$. Severe quality of life (QoL) impairment is evident in a significant proportion of adults with GHD, and the beneficial effects of physiological GH replacement on QoL in affected individuals are well documented [53-55]. However, the risk of adverse effects may increase in the GHD adults treated with GH, such as oedema, joint stiffness, and carpal tunnel syndrome [54]. Moreover, serum IGF1 levels increase in the GHD patients with GH treatment. In the general population, higher circulating IGF1 levels are associated with increased incidence of prostate, colorectal, and premenopausal breast cancer [56]. To date, however, there have been no published long-term studies in adults with GHD treated with GH with respect to the development of nonpituitary malignancies.

The present study has some limitations that should be considered. Firstly, because only studies that were indexed by the selected databases were included for data analysis, some relevant published studies or unpublished studies might be missed, which might have biased our results. Secondly, our meta-analysis only included adult subjects since it was inappropriate to pool data from studies in children, where growth had a major effect of GH therapy; with studies in adults, this was not the case.

\section{Conclusions}

Considered together, these studies seem to indicate that GH treatment had beneficial influence on BMD in GHD adults, but in some subject populations, the influence was not evident.

\section{Conflict of Interests}

None of the authors has any conflict of interests to declare.

\section{Authors' Contributions}

P. Xue and Y. Wang contributed equally to this work.

\section{Acknowledgments}

This work was supported by the National Natural Science Foundation of Hebei Province (no. C2009001179) and Grant from Hebei Provincial Health Bureau (no. 20090316).

\section{References}

[1] I. Shimon, "Growth hormone replacement for adult growth hormone deficiency," Expert Opinion on Pharmacotherapy, vol. 4, no. 11, pp. 1977-1983, 2003.

[2] M. Ernst and E. R. Froesch, "Growth hormone dependent stimulation of osteoblast-like cells in serum-free cultures via 
local synthesis of insulin-like growth factor I," Biochemical and Biophysical Research Communications, vol. 151, no. 1, pp. 142-147, 1988.

[3] Y. H. Joung, E. J. Lim, P. Darvin et al., "MSM enhances GH signaling via the Jak2/STAT5b pathway in osteoblast-like cells and osteoblast differentiation through the activation of STAT5b in MSCs," PLoS One, vol. 7, no. 10, Article ID e47477, 2012.

[4] P. V. Carroll, E. R. Christ, B. Å. Bengtsson et al., "Growth hormone deficiency in adulthood and the effects of growth hormone replacement: a review," Journal of Clinical Endocrinology and Metabolism, vol. 83, no. 2, pp. 382-395, 1998.

[5] A. Geisler, N. Lass, N. Reinsch et al., "Quality of life in children and adolescents with growth hormone deficiency: association with growth hormone treatment," Hormone Research in Paediatrics, vol. 78, no. 2, pp. 94-99, 2012.

[6] P. Kann, B. Piepkorn, B. Schehler et al., "Effect of longterm treatment with $\mathrm{GH}$ on bone metabolism, bone mineral density and bone elasticity in GH-deficient adults," Clinical Endocrinology, vol. 48, no. 5, pp. 561-568, 1998.

[7] N. A. Tritos, A. H. Hamrahian, D. King et al., "A longer interval without GH replacement and female gender are associated with lower bone mineral density in adults with childhood-onset GH deficiency: a KIMS database analysis," European Journal of Endocrinology, vol. 167, no. 3, pp. 343-351, 2012.

[8] C. Wüster, R. Abs, B. A. Bengtsson et al., "The influence of growth hormone deficiency, growth hormone replacement therapy, and other aspects of hypopituitarism on fracture rate and bone mineral density," Journal of Bone and Mineral Research, vol. 16, no. 2, pp. 398-405, 2001.

[9] T. Rosén, L. Wilhelmsen, K. Landin-Wilhelmsen, G. Lappas, and B. Å. Bengtsson, "Increased fracture frequency in adult patients with hypopituitarism and GH deficiency," European Journal of Endocrinology, vol. 137, no. 3, pp. 240-245, 1997.

[10] H. L. Fideleff, H. R. Boquete, G. Stalldecker, A. V. Giaccio, and P. G. V. Sobrado, "Comparative results of a 4-year study on cardiovascular parameters, lipid metabolism, body composition and bone mass between untreated and treated adult growth hormone deficient patients," Growth Hormone and IGF Research, vol. 18, no. 4, pp. 318-324, 2008.

[11] S. van den Heijkant, G. Hoorweg-Nijman, J. Huisman et al., "Effects of growth hormone therapy on bone mass, metabolic balance, and well-being in young adult survivors of childhood acute lymphoblastic leukemia," Journal of Pediatric Hematology/Oncology, vol. 33, no. 6, pp. e231-e238, 2011.

[12] N. Suganuma, M. Furuhashi, T. Hirooka et al., "Bone mineral density in adult patients with Turner's syndrome: analyses of the effectiveness of GH and ovarian steroid hormone replacement therapies," Endocrine Journal, vol. 50, no. 3, pp. 263-269, 2003.

[13] T. B. Hansen, K. Brixen, N. Vahl et al., "Effects of 12 months of growth hormone $(\mathrm{GH})$ treatment on calciotropic hormones, calcium homeostasis, and bone metabolism in adults with acquired GH deficiency: a double blind, randomized, placebo-controlled study," Journal of Clinical Endocrinology and Metabolism, vol. 81, no. 9, pp. 3352-3359, 1996.

[14] G. Johannsson, T. Rosén, I. Bosaeus, L. Sjöström, and B. Å. Bengtsson, "Two years of growth hormone $(\mathrm{GH})$ treatment increases bone mineral content and density in hypopituitary patients with adult-onset GH deficiency," Journal of Clinical Endocrinology and Metabolism, vol. 81, no. 8, pp. 2865-2873, 1996.
[15] J. Rodríguez-Arnao, I. James, A. Jabbar et al., "Serum collagen crosslinks as markers of bone turn-over during GH replacement therapy in growth hormone deficient adults," Clinical Endocrinology, vol. 48, no. 4, pp. 455-462, 1998.

[16] R. C. Cuneo, S. Judd, J. D. Wallace et al., "The Australian multicenter trial of growth hormone (GH) treatment in GH- deficient adults," Journal of Clinical Endocrinology and Metabolism, vol. 83, no. 1, pp. 107-116, 1998.

[17] B. M. K. Biller, G. Sesmilo, H. B. A. Baum, D. Hayden, D. Schoenfeld, and A. Klibanski, "Withdrawal of long-term physiological growth hormone $(\mathrm{GH})$ administration: differential effects on bone density and body composition in men with adult-onset GH deficiency," Journal of Clinical Endocrinology and Metabolism, vol. 85, no. 3, pp. 970-976, 2000.

[18] J. Koranyi, J. Svensson, G. Götherström, K. S. Sunnerhagen, B. Å. Bengtsson, and G. Johannsson, "Baseline characteristics and the effects of five years of GH replacement therapy in adults with GH deficiency of childhood or adulthood onset: a comparative, prospective study," Journal of Clinical Endocrinology and Metabolism, vol. 86, no. 10, pp. 4693-4699, 2001.

[19] R. Lanzi, M. Losa, I. Villa et al., "GH replacement therapy increases plasma osteoprotegerin levels in GH-deficient adults," European Journal of Endocrinology, vol. 148, no. 2, pp. 185-191, 2003.

[20] L. E. Underwood, K. M. Attie, and J. Baptista, "Growth hormone $(\mathrm{GH})$ dose-response in young adults with childhoodonset GH deficiency: a two-year, multicenter, multiple-dose, Placebo-controlled study," Journal of Clinical Endocrinology and Metabolism, vol. 88, no. 11, pp. 5273-5280, 2003.

[21] E. Hubina, L. Kovacs, I. Szabolcs et al., "The effect of gender and age on growth hormone replacement in growth hormonedeficient patients," Hormone and Metabolic Research, vol. 36, no. 4, pp. 247-253, 2004.

[22] N. Bravenboer, P. J. Holzmann, J. C. Ter Maaten, L. M. Stuurman, J. C. Roos, and P. Lips, "Effect of long-term growth hormone treatment on bone mass and bone metabolism in growth hormone-deficient men," Journal of Bone and Mineral Research, vol. 20, no. 10, pp. 1778-1784, 2005.

[23] L. I. Arwert, J. C. Roos, P. Lips, J. W. R. Twisk, R. A. Manoliu, and M. L. Drent, "Effects of 10 years of growth hormone (GH) replacement therapy in adult GH-deficient men," Clinical Endocrinology, vol. 63, no. 3, pp. 310-316, 2005.

[24] C. L. Boguszewski, L. H. F. Meister, D. C. T. Zaninelli, and R. B. Radominski, "One year of GH replacement therapy with a fixed low-dose regimen improves body composition, bone mineral density and lipid profile of GH-deficient adults," European Journal of Endocrinology, vol. 152, no. 1, pp. 67-75, 2005.

[25] S. Benedini, L. Dalle Carbonare, N. Albiger et al., "Effect of short-term therapy with recombinant human growth hormone (GH) on metabolic parameters and preclinical atherosclerotic markers in hypopituitary patients with growth hormone deficiency," Hormone and Metabolic Research, vol. 38, no. 1, pp. 1621, 2006.

[26] P. J. Snyder, B. M. K. Biller, A. Zagar et al., "Effect of growth hormone replacement on BMD in adult-onset growth hormone deficiency," Journal of Bone and Mineral Research, vol. 22, no. 5, pp. 762-770, 2007.

[27] G. Gotherstrom, B. A. Bengtsson, I. Bossæus, G. Johansson, and J. Svensson, "Ten-year GH replacement increase bone mineral density in hypopituitary patients with adult onset GH deficiency," European Journal of Endocrinology, vol. 156, no. 1, pp. 55-64, 2007. 
[28] F. Rota, M. C. Savanelli, L. Tauchmanova et al., "Bone density and turnover in young adult patients with growth hormone deficiency after 2-year growth hormone replacement according with gender," Journal of Endocrinological Investigation, vol. 31, no. 2, pp. 94-103, 2008.

[29] G. S. Conway, M. Szarras-Czapnik, K. Racz et al., “Treatment for 24 months with recombinant human GH has a beneficial effect on bone mineral density in young adults with childhood-onset GH deficiency," European Journal of Endocrinology, vol. 160, no. 6, pp. 899-907, 2009.

[30] M. Elbornsson, G. Gotherstrom, I. Bosaeus, B. A. Bengtsson, G. Johannsson, and J. Svensson, "Fifteen years of GH replacement increases bone mineral density in hypopituitary patients with adult-onset GH deficiency," European Journal of Endocrinology, vol. 166, no. 5, pp. 787-795, 2012.

[31] D. W. Leung, S. A. Spencer, G. Cachianes et al., "Growth hormone receptor and serum binding protein: purification, cloning and expression," Nature, vol. 330, no. 6148, pp. 537-543, 1987.

[32] M. Andreassen, J. Frystyk, J. Faber, and L. O. Kristensen, "GH activity and markers of inflammation: a crossover study in healthy volunteers treated with GH and a $\mathrm{GH}$ receptor antagonist," European Journal of Endocrinology, vol. 166, no. 5, pp. 811-819, 2012.

[33] L. S. Mathews, R. E. Hammer, R. L. Brinster, and R. D. Palmiter, "Expression of insulin-like growth factor I in transgenic mice with elevated levels of growth hormone is correlated with growth," Endocrinology, vol. 123, no. 1, pp. 433-437, 1988.

[34] N. S. Becker, P. Verdu, M. Georges et al., "The role of GHR and IGF1 genes in the genetic determination of African pygmies' short stature," European Journal of Human Genetics, 2012.

[35] C. Barner, M. Petersson, B. Eden Engstrom, Hoybye, and C. :, "Effects on insulin sensitivity and body composition of combination therapy with GH and IGF1 in GH deficient adults with type 2 diabetes," European Journal of Endocrinology, vol. 167, no. 5, pp. 697-703, 2012.

[36] J. M. P. Holly and J. A. H. Wass, "Insulin-like growth factors; autocrine, paracrine or endocrine? New perspectives of the somatomedin hypothesis in the light of recent developments," Journal of Endocrinology, vol. 122, no. 3, pp. 611-618, 1989.

[37] F. I. Arnaldez and L. J. Helman, "Targeting the insulin growth factor receptor 1," Hematology/Oncology Clinics of North America, vol. 26, no. 3, pp. 527-542, 2012.

[38] S. Yakar, C. J. Rosen, W. G. Beamer et al., "Circulating levels of IGF-1 directly regulate bone growth and density," Journal of Clinical Investigation, vol. 110, no. 6, pp. 771-781, 2002.

[39] M. Kassem, L. Mosekilde, and E. F. Eriksen, "Growth hormone stimulates proliferation of normal human bone marrow stromal osteoblast precursor cells in vitro," Growth Regulation, vol. 4, no. 3, pp. 131-135, 1994.

[40] J. M. Wit and C. Camacho-Hubner, "Endocrine regulation of longitudinal bone growth," Endocrine Development, vol. 21, pp. 30-41, 2011.

[41] G. I. Baroncelli, S. Bertelloni, C. Ceccarelli, D. Cupelli, and G. Saggese, "Dynamics of bone turnover in children with GH deficiency treated with GH until final height," European Journal of Endocrinology, vol. 142, no. 6, pp. 549-556, 2000.

[42] O. Klefter and U. Feldt-Rasmussen, "Is increase in bone mineral content caused by increase in skeletal muscle mass/strength in adult patients with GH-treated GH deficiency? A systematic literature analysis," European Journal of Endocrinology, vol. 161, no. 2, pp. 213-221, 2009.
[43] D. N. Proctor, L. J. Melton, S. Khosla, C. S. Crowson, M. K. O'Connor, and B. L. Riggs, "Relative influence of physical activity, muscle mass and strength on bone density," Osteoporosis International, vol. 11, no. 11, pp. 944-952, 2000.

[44] H. M. Frost, “The Utah paradigm of skeletal physiology: an overview of its insights for bone, cartilage and collagenous tissue organs," Journal of Bone and Mineral Metabolism, vol. 18, no. 6, pp. 305-316, 2000.

[45] A. Giustina, G. Mazziotti, and E. Canalis, "Growth hormone, insulin-like growth factors, and the skeleton," Endocrine Reviews, vol. 29, no. 5, pp. 535-559, 2008.

[46] A. Kaur and S. R. Phadke, "Analysis of short stature cases referred for genetic evaluation," The Indian Journal of Pediatrics, vol. 79, no. 12, pp. 1597-1600, 2012.

[47] R. D. Murray, C. J. Skillicorn, S. J. Howell, C. A. Lissett, A. Rahim, and S. M. Shalet, "Dose titration and patient selection increases the efficacy of $\mathrm{GH}$ replacement in severely $\mathrm{GH}$ deficient adults," Clinical Endocrinology, vol. 50, no. 6, pp. 749757, 1999.

[48] N. A. Pocock, K. A. Noakes, M. Griffiths et al., "A comparison of longitudinal measurements in the spine and proximal femur using lunar and hologic instruments," Journal of Bone and Mineral Research, vol. 12, no. 12, pp. 2113-2118, 1997.

[49] W. M. Drake, J. Rodríguez-Arnao, J. U. Weaver et al., "The influence of gender on the short and long-term effects of growth hormone replacement on bone metabolism and bone mineral density in hypopituitary adults: a 5-year study," Clinical Endocrinology, vol. 54, no. 4, pp. 525-532, 2001.

[50] L. E. Olson, C. Ohlsson, and S. Mohan, "The role of GH/IGF-Imediated mechanisms in sex differences in cortical bone size in mice," Calcified Tissue International, vol. 88, no. 1, pp. 1-8, 2011.

[51] P. V. Carroll, W. M. Drake, K. T. Maher et al., "Comparison of continuation or cessation of growth hormone (GH) therapy on body composition and metabolic status in adolescents with severe GH deficiency at completion of linear growth," Journal of Clinical Endocrinology and Metabolism, vol. 89, no. 8, pp. 38903895, 2004.

[52] V. K. B. Prabhakar and S. M. Shalet, "Aetiology, diagnosis, and management of hypopituitarism in adult life," Postgraduate Medical Journal, vol. 82, no. 966, pp. 259-266, 2006.

[53] L. J. Woodhouse, A. Mukherjee, S. M. Shalet, and S. Ezzat, "The influence of growth hormone status on physical impairments, functional limitations, and health-related quality of life in adults," Endocrine Reviews, vol. 27, no. 3, pp. 287-317, 2006.

[54] A. Hazem, M. B. Elamin, I. Bancos et al., "Body composition and quality of life in adults treated with GH therapy: a systematic review and meta-analysis," European Journal of Endocrinology, vol. 166, no. 1, pp. 13-20, 2012.

[55] J. B. Deijen, L. I. Arwert, J. Witlox, and M. L. Drent, "Differential effect sizes of growth hormone replacement on quality of life, well-being and health status in growth hormone deficient patients: a meta-analysis," Health and Quality of Life Outcomes, vol. 3, p. 63, 2005.

[56] A. G. Renehan, M. Zwahlen, C. Minder, S. T. O’Dwyer, S. M. Shalet, and M. Egger, "Insulin-like growth factor (IGF)-I, IGF binding protein-3, and cancer risk: systematic review and metaregression analysis," The Lancet, vol. 363, no. 9418, pp. 13461353, 2004. 


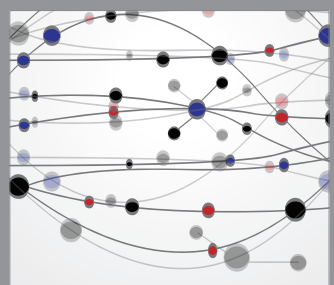

The Scientific World Journal
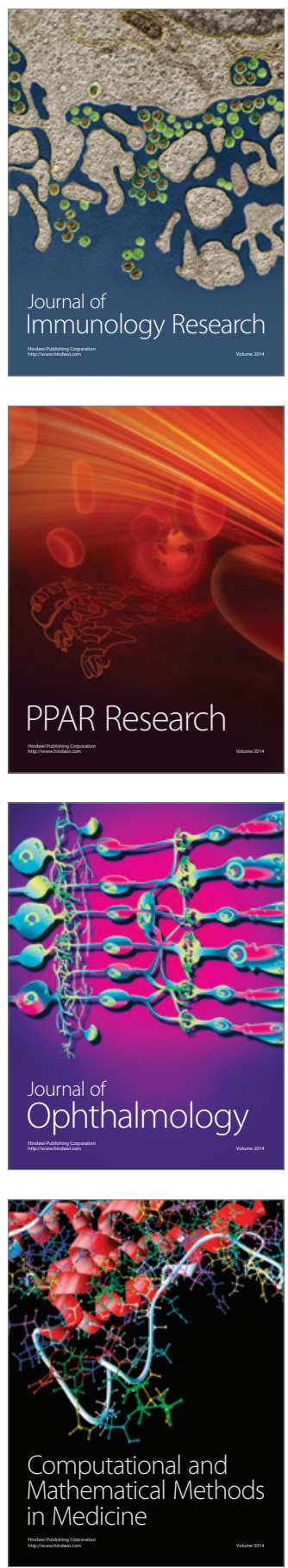

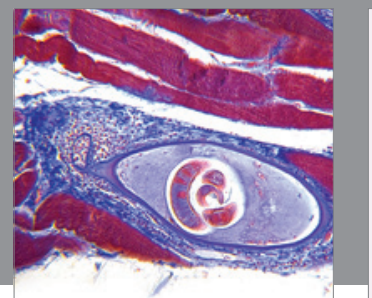

Gastroenterology

Research and Practice
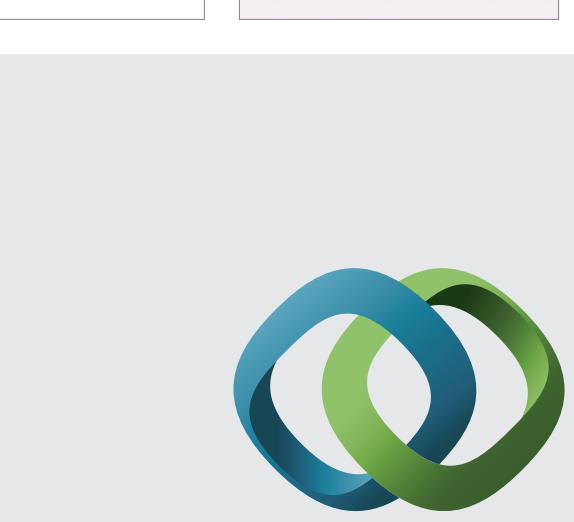

\section{Hindawi}

Submit your manuscripts at

http://www.hindawi.com
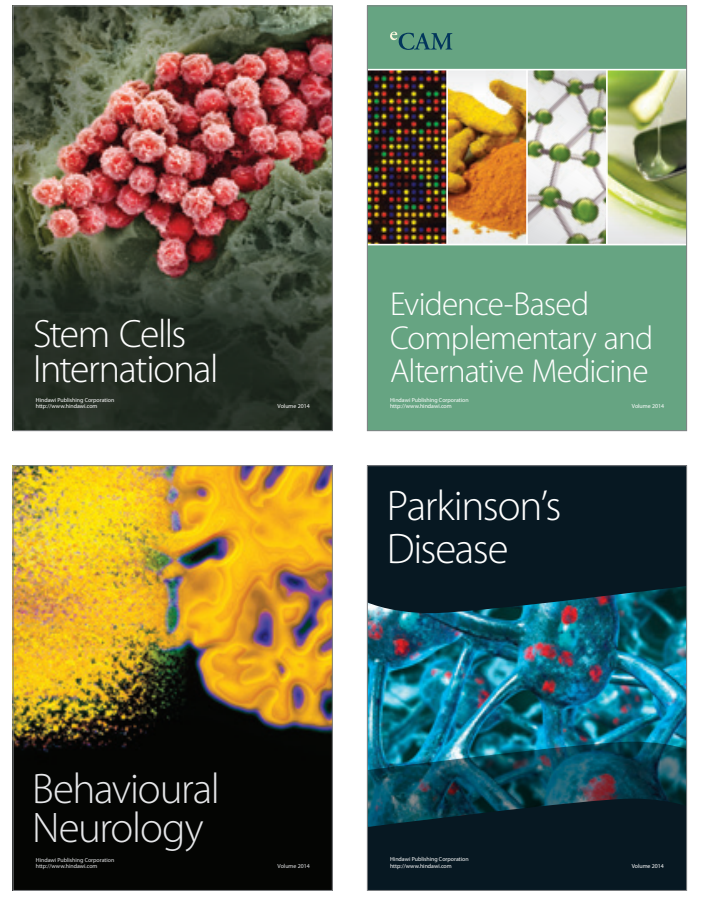
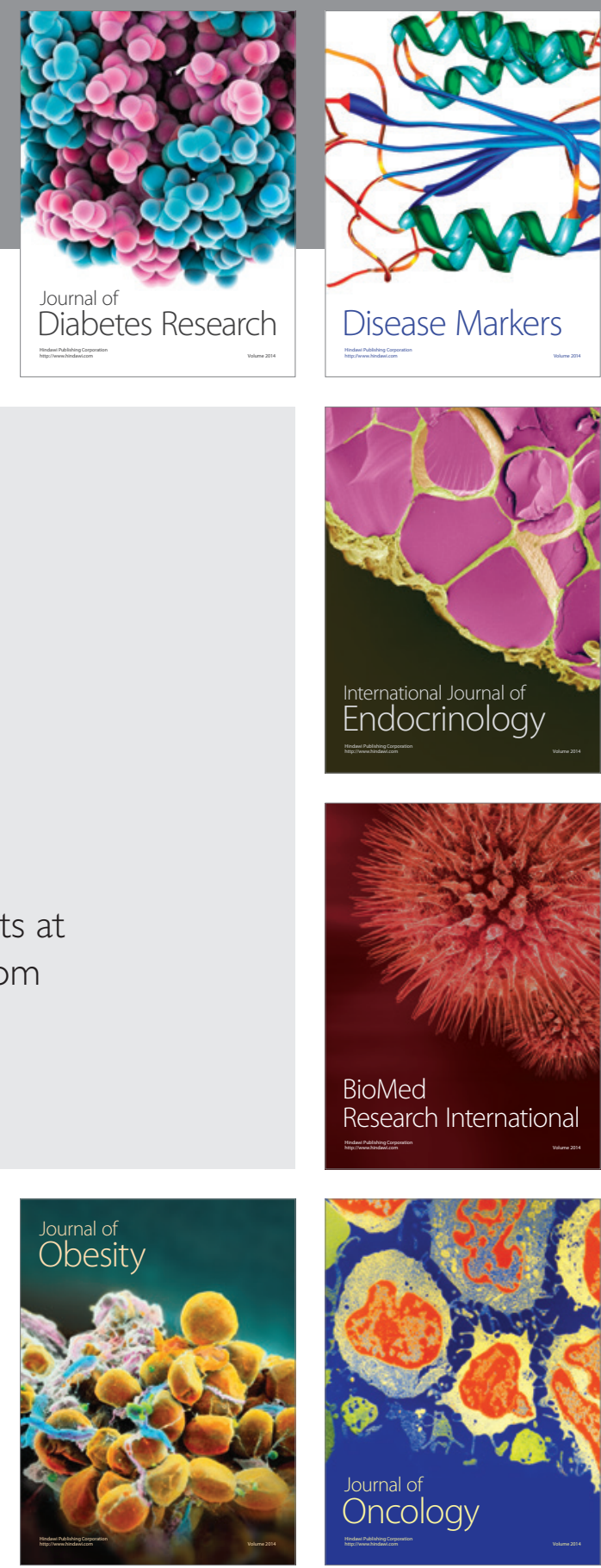

Disease Markers
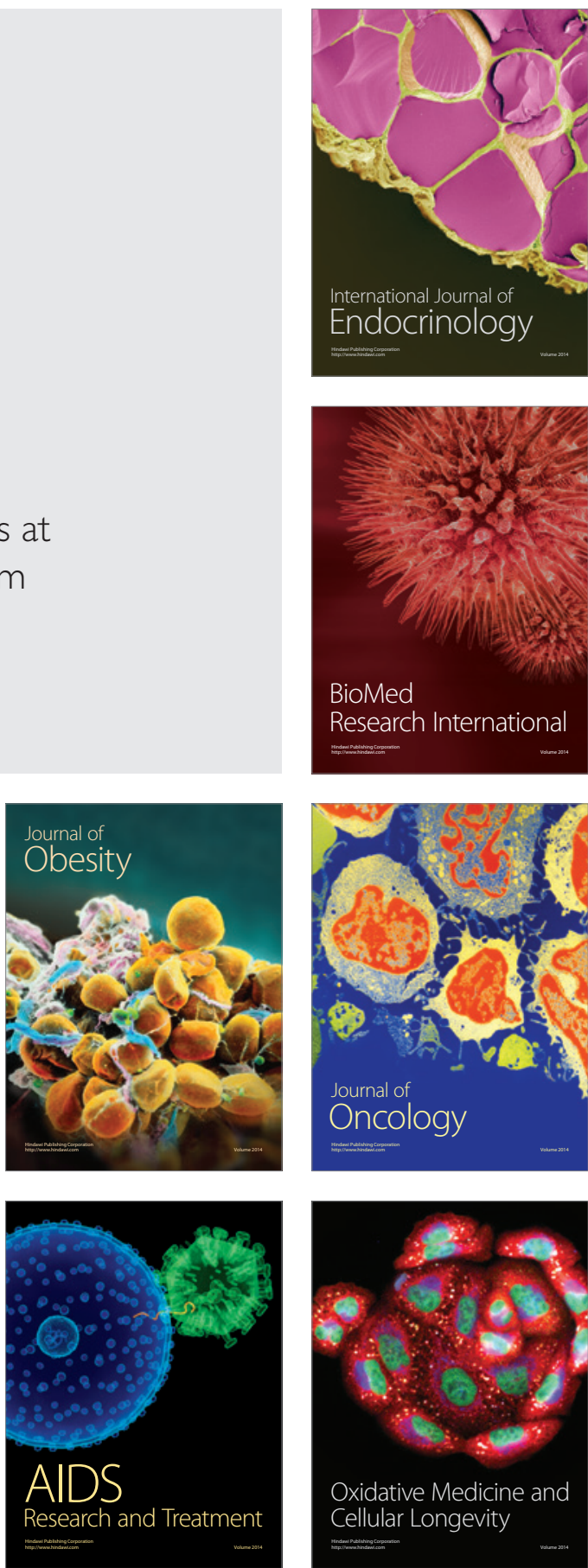